\title{
EFFECTS OF HIGH CARBON DIOXIDE LEVEL ON THE EMERGENCE OF OIL PALM POLLINATING WEEVIL, Elaeidobius kamerunicus
}

\author{
AMANINA, N S*; HASNUDIN, M Y*; HANIFF, M H*; ROSLAN, M N*; A'FIFAH, A R* and RAMLE, $M^{*}$
}

\begin{abstract}
Elaeidobius kamerunicus is the main pollinating insect of oil palm in Malaysia. The increase of ambient carbon dioxide $\left(\mathrm{CO}_{2}\right)$ may promote greater crop growth and yield of oil palm. However, E. kamerunicus' adaptability and survival under high $\mathrm{CO}_{2}$ level are still unknown. An oil palm weevil emergence study was conducted in plant growth chambers with two $\mathrm{CO}_{2}$ levels, 400 ppm and $800 \mathrm{ppm}$. The plant growth chambers were set at $27^{\circ} \mathrm{C}$ and $70 \%$ relative humidity for the entire study period. Spikelets were taken from apical, middle and basal regions of anthesising male inflorescences from 6-year old DxP palms under normal field conditions. The sampled spikelets were placed in clear plastic tubes with both open ends covered with muslin cloth. The emergence of adults was observed at two-day interval until 10 days after incubation. The total number of weevils which emerged from the spikelets at $400 \mathrm{ppm}$ and $800 \mathrm{ppm} \mathrm{CO} \mathrm{CO}_{2}$ levels were 240 and 233 individuals, respectively. Doubling the ambient $\mathrm{CO}_{2}$ level to 800 ppm had no effect on $\mathrm{E}$. kamerunicus emergence in controlled condition. Further study on oil palm weevil adaptability and survival under high $\mathrm{CO}_{2}$ level is needed to provide information on the effects of future climate change scenario and oil palm yield.
\end{abstract}

Keywords: Elaeidobius kamerunicus, oil palm pollinating insect, high $\mathrm{CO}_{2}$

Date received: 17 September 2015; Sent for revision: 11 October 2015; Received in final form: 29 February 2016; Accepted: 1 March 2016.

\section{INTRODUCTION}

Over the next century, the atmospheric concentration of carbon dioxide $\left(\mathrm{CO}_{2}\right)$ is anticipated to double (Watson et al., 1996). Since 1970 to 2004, its annual emission increased by about $80 \%$ and the projection to continue to increase as much as $500-1000$ ppm by the year 2100 (IPCC, 2007). Two profound effects on individual species and communities are expected: first, on the fertilising effect of $\mathrm{CO}_{2}$ on plant growth and second, on changes in climate. The direct physiological effects of enriched $\mathrm{CO}_{2}$ atmospheres for plant species are becoming increasingly well

\footnotetext{
Malaysian Palm Oil Board,

6, Persiaran Institusi, Bandar Baru Bangi,

43000 Kajang, Selangor, Malaysia.

E-mail: nuramanina@mpob.gov.my
}

documented (Curtis and Wang, 1998). Several of these effects may alter the quality and quantity of food available for insect herbivores. First, many $\mathrm{C}_{3}$ plants (rice, soyabean, peanut, potato, shrubs and trees) raised in $\mathrm{CO}_{2}$-enriched atmospheres have higher photosynthetic rates and grow faster, increasing the biomass of plant materials available to herbivorous insects.

The oil palm (Elaeis guineensis), being a $\mathrm{C}_{3}$ plant, is expected to positively respond to increasing $\mathrm{CO}_{2}$ levels thereby resulting to increase in growth biomass and fresh fruit bunch yield. Under high $\mathrm{CO}_{2}$ condition, the fertilising effect can boost yield of $\mathrm{C}_{3}$ crops by about 13\% (Chandler and Le Page, 2007). Fruit bunch production of oil palm is influenced by the availability of nutrients, water, carbohydrate supply and pollination. Poor fruit set may result in bunch failure and losses in oil yield (Mohd Haniff and Mohd Roslan, 2002). 
Oil palm is entomophilous (Syed, 1979) such that its pollination efficiency is dependent on pollen supply and pollinator activity (Mohd Haniff and Mohd Roslan, 2002). Before the introduction of oil palm weevil (Elaeidobius kamerunicus), manual assisted pollination was implemented. This method was an expensive and labour-intensive operation (Basri, 1984). Pollens had to be harvested from anthesising male inflorescences and sprayed onto anthesising female flowers. Elaeidobius kamerunicus was brought into Malaysia in early 1982 to improve pollination efficiency (Syed et al., 1982). This species is the most effective oil palm pollinator in Malaysia, even during wet season (Mohd Basri and Norman, 1997). The adult weevils feed and breed on male inflorescences at anthesis (Basri, 1984) and have close relationship with oil palm (Yue et al., 2015). Weevil pollination increases fruit set and subsequently improves the oil palm yield (Ponnamma, 1999; Caudwell, 2011).

Commercial plantations with different palm ages need to maintain a suitable population level of E. kamerunicus (Bulgarellil et al., 2002). This weevil carries more pollen and has good searching ability (Syed et al., 1981). Population dynamic and activity of oil palm weevil are influenced by climatic conditions (Chee and Chiu, 1998). However, there is a lack of information on the weevil performance under high $\mathrm{CO}_{2}$ condition. In this study, we focused on the effect of elevated $\mathrm{CO}_{2}$ at double the ambient $\mathrm{CO}_{2}$ level on the emergence of E. kamerunicus in controlled condition.

\section{MATERIALS AND METHODS}

The experiment was conducted in two walk-in plant growth chambers $(3.1 \mathrm{~m}$ width $\times 4.7 \mathrm{~m}$ length $\times 2.9 \mathrm{~m}$ high) with temperature at $27^{\circ} \mathrm{C}$, relative humidity at $70 \%$, photosynthetically active radiation (PAR) level at $55 \mu \mathrm{mol} \mathrm{m} \mathrm{m}^{-2} \mathrm{~s}^{-1}$ and two $\mathrm{CO}_{2}$ concentrations; 400 ppm and 800 ppm. These chambers were located at MPOB Research Station in Kluang, Johor, Malaysia (157.377 N, $\left.103^{\circ} 22.286 \mathrm{E}\right)$.

Two nearly-anthesised male inflorescences were randomly selected from six year-old DxP palms growing in a nearby field (temperature $26^{\circ} \mathrm{C}, \mathrm{CO}_{2}$ 399 ppm and relative humidity 79\%). They were covered with terylene bags to prevent from getting soaked in the rain (Figure 1a). However, the bags were not sealed in order to allow the active weevils to breed in the spikelets.

After three days, the anthesised male inflorescences were sampled between $0900 \mathrm{H}$ and $1100 \mathrm{H}$ in the morning and brought back to the laboratory (Figure 1b). Three spikelets each from basal, middle and apical regions of the inflorescences were cut and placed in a transparent plastic tube $(5.1 \mathrm{~cm}$ diameter $\times 16.5 \mathrm{~cm}$ high) (Figure 1c). Both openings of the plastic tube were covered with muslin cloth to ensure good ventilation and to remove any water condensation produced from the spikelets (Figures $1 d$ and 1e). A total of 10 tubes per treatment were placed at an angle of about $15^{\circ}$ for better aeration and to drain any water condensation (Figure 1f). The number of emerged weevils was recorded at 10 days after incubation (DAI) in the plant growth chambers. According to Tuo et al. (2011), duration of the developmental stages of E. kamerunicus is 10.27 days, which includes egg stage, neonate stage, larva stage, nymph stage and adult stage.

\section{RESULTS AND DISCUSSION}

Figure 2 shows the emergence of pollinating weevil at $400 \mathrm{ppm}$ and $800 \mathrm{ppm}$ of $\mathrm{CO}_{2}$. The results showed that the number of weevil emerged from the spikelets were low for six DAI, but then rapidly increased after eight days onwards. The number of emerging weevils for both treatments was too high at eight DAI (Figure 3). At Day 10, the weevils were euthanised using a commercial insecticide spray and the number of dead weevils were counted and recorded.

Final counting at 10 DAI showed that the number of weevil emerged in treatments $400 \mathrm{ppm}$ and 800 ppm of $\mathrm{CO}_{2}$ were 240 and 233 individuals, respectively. They are not significantly different at $\mathrm{p}=0.05$ between the $\mathrm{CO}_{2}$ treatments (Table 1 ). This suggested that the 800 ppm of $\mathrm{CO}_{2}$ did not affect the weevil emergence under controlled condition.

Other studies have shown that $\mathrm{CO}_{2}$ can have adverse effect to insects when applied at very high concentration. For example, fumigation using $\mathrm{CO}_{2}$ can only be effective to kill insects when it is applied at 400000 ppm for over 7-15 days (Kathleen

TABLE 1. EMERGING WEEVILS RECORDED AT DAY 10 AFTER INCUBATION

\begin{tabular}{lcc}
\hline & \multicolumn{2}{c}{ Level of $\mathrm{CO}_{2}$} \\
\cline { 2 - 3 } & $400 \mathrm{ppm}$ & $800 \mathrm{ppm}$ \\
\hline 3 spikelets (basal, middle and apical) in each tube & $240.00 \pm 15.93 \mathrm{a}$ & $233.10 \pm 14.56 \mathrm{a}$ \\
\hline
\end{tabular}

Note: Mean \pm SE. Values with the same letter are not significantly different at $\mathrm{p}<0.05$. 

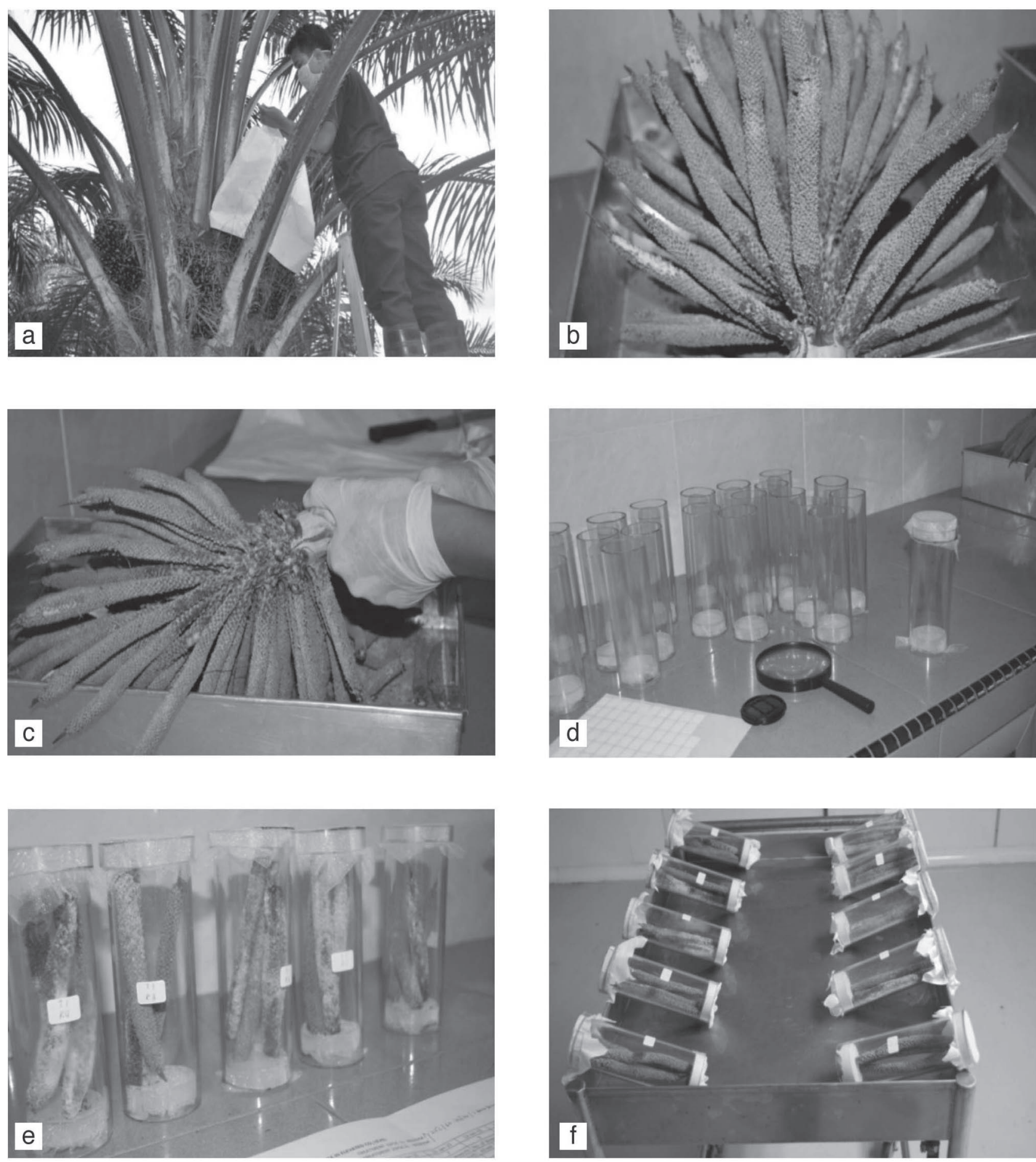

Figure 1. (a) Male inflorescence before anthesis was enclosed in a terylene bag, (b) fresh anthesising male inflorescence was brought to the laboratory, (c) spikelets were taken from apical, middle and basal regions, (d) transparent tubes with their openings covered by muslin cloth were prepared, (e) three spikelets were placed inside the transparent tube and the openings covered with muslin cloth, (f) the transparent tubes were incubated in each plant growth chamber at $27^{\circ} \mathrm{C}, 70 \% \mathrm{RH}$ and $55 \mu \mathrm{mol} \mathrm{m} \mathrm{m}^{-2} \mathrm{~s}^{-1}$ light level for 10 days.

et al., 1995). If the $\mathrm{CO}_{2}$ level was kept high and long enough, it would kill all the adults and the offspring that normally hatch several days later. Level of $\mathrm{CO}_{2}$ greater than $0.5 \%$ (5000 ppm) could have adverse health effects to humans, animals and plants (Bardiya et al., 2013).

\section{CONCLUSION}

The emergence of oil palm pollinating weevil, E. kamerunicus was not affected when incubated in $800 \mathrm{ppm}$ of $\mathrm{CO}_{2}$ under controlled environment condition of the plant growth chamber. Further 


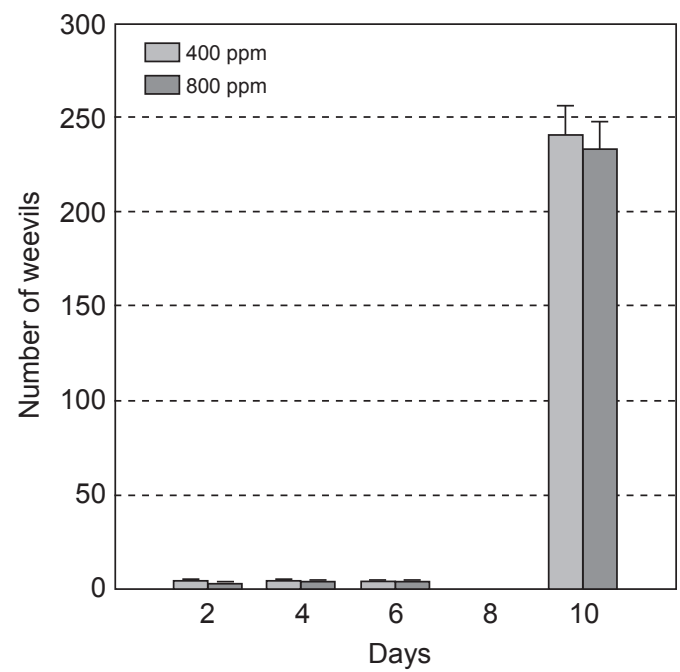

Figure 2. Number of emerging weevils in each tube recorded at twoday interval under the 400 and $800 \mathrm{ppm} \mathrm{CO}_{2}$ treatments.

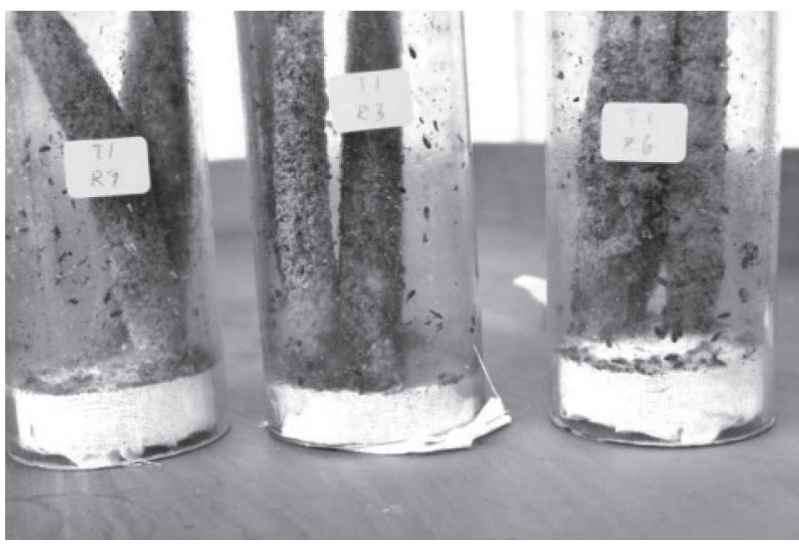

Figure 3. The number of emerging weevils was too high at Day 8 after incubation for both treatments before they were euthanised using a commercial insecticide spray. Then, the number of dead weevils were counted and recorded.

study is still needed to evaluate the effect of high concentration of $\mathrm{CO}_{2}$ especially on life table and activity of the E. kamerunicus.

\section{ACKNOWLEDGEMENT}

We would like to thank the Director-General of MPOB for permission to publish this article. The support of the Director of Biological Research, MPOB is greatly appreciated. We also thank members of the Crop Physiology Group for their assistance in carrying out this study.

\section{REFERENCES}

BARDIYA, M S; POWAR, R S and KULKARNI, P $\mathrm{R}$ (2013). Safety aspects of $\mathrm{CO}_{2}$ as a refrigerant. Second International Conference on Emerging Trends in Engineering (SICETE). IOSR J. Mechanical Engineering (IOSR-JMCE), 6(58): 35-39.
BASRI, M W (1984). Developments of the oil palm pollinator, Elaeidobius kamerunicus in Malaysia. Palm Oil Developments No. 2: 1-3.

BULGARELLIL, J; CHINCHILLA, $\mathrm{C}$ and RODRIGUEZ, R (2002). Male inflorescences, population of Elaeidobius kamerunicus and pollination in a young commercial oil palm plantation in a dry area of Costa Rica. ASD Oil Palm Papers, 24: 32-37.

CAUDWELL, R W (2001). Insect pollination of oil palm - time to evaluate the long-term viability and sustainability of Elaeidobius kamerunicus? Planter, 77 (901): 181-190.

CHANDLER, D and LE PAGE, M (2007). Climate myths: higher $\mathrm{CO}_{2}$ level will boost plant growth and production. www.newscientist.com/article / dn11655, accessed on 16 May 2007.

CHEE, K H and CHIU, S B (1998). A study of Elaeidobius kamerunicus in West Kalimantan oil palm plantations. Planter, 74 (872): 587-595.

CURTIS, P S and WANG, X (1998). A meta-analysis of elevated $\mathrm{CO}_{2}$ effects on woody plant mass, form and physiology. Oecologia, 113: 299-313.

IPCC (2007). Climate Change 2007: The Physical Science Basis. Contribution of Working Group I to the Fourth Assessment Report of the Intergovernmental Panel on Climate Change. Cambridge University Press, Cambridge, UK.

KATHLEEN M DELATE; J KENNETH GRACE; JOHN W ARMSTRONG and CARRIE H M TOME (1995). Carbon dioxide as a potential fumigant for termite control. Pesticide Science, 44: 357-361.

MOHD BASRI WAHID and NORMAN KAMARUDIN (1997). Role and effectiveness of Elaeidobius kamerunicus, Thrips hawaiiensis and Pyroderces sp. in pollination of mature oil palm in Peninsular Malaysia. Elaeis, 9 (1): 1-16.

MOHD HANIFF HARUN and MOHD ROSLAN MD NOOR (2002). Fruit set and oil palm bunch components. J. Oil Palm Res. Vol. 14 (2): 24-33.

PONNAMMA, K N (1999). Diurnal variation in the population of Elaeidobius kamerunicus on the anthesizing male inflorescence of oil palm. Planter, 75 (881): 405-410.

SYED, R A (1979). Studies on oil palm pollination by insects. Bulletin of Entomological Research, 69: 213-224.

SYED, R A; PUSPARAJAH, E and SOON, C P (1981). Insect pollination of oil palm: feasibility of 
introducing Elaeidobius spp. into Malaysia. The oil palm in the eighties. Report of the Proc. of the International Conference on Oil Palm in Agriculture in the Eighties. Volume 1. p. 263-289.

SYED, R A; LAW, I H and CORLEY, R H V (1982). Insect pollination of oil palm: introduction, establishment and pollinating efficiency of Elaeidobius kamerunicus in Malaysia. Planter, 58: 547561.

TUO, Y; KOUA, H K and HALA, N (2011). Biology of Elaeidobius kamerunicus and Elaeidobius plagiatus (Coleoptera: Curculionidae) main pollinators of oil palm in West Africa. European J. Scientific Research, 49 (3): 426-432.
WATSON R T; ZINYOWERA, M C and MOSS, R H (eds.). (1996). Climate Change 1995. Impacts, Adaptations and Mitigation of Climate Change: Scientific-technical Analyses. Contribution of the Work Group II to the Second Assessment Report of the Intergovernmental Panel on Climate Change. Cambridge University Press, Cambridge, United Kingdom.

YUE, J; YAN, Z; BAI, C; CHEN, Z; LIN, W and JIAO, F (2015). Pollination activity of Elaeidobius kamerunicus (Coleoptera: Curculioniodea) on oil palm on Hainan island. Florida Entomologist, 98 (2): 499-505. 